\title{
Erratum to: Developing biotechnology tools for 'beautiful' vavilovia (Vavilovia formosa), a legume crop wild relative with taxonomic and agronomic potential
}

\author{
Sergio Ochatt ${ }^{1} \cdot$ Catherine Conreux $^{1} \cdot$ Iva Smýkalová $^{2} \cdot$ Petr Smýkal $^{3}$. \\ Aleksandar Mikić ${ }^{4}$
}

Published online: 8 December 2016

(C) Springer Science+Business Media Dordrecht 2016

\section{Erratum to: Plant Cell Tiss Organ Cult DOI 10.1007/s11240-016-1133-z}

In the original version of this article, the authors' given names and family names were presented incorrectly. The original article was corrected.

The online version of the original article can be found under doi:10.1007/s11240-016-1133-z.

Sergio Ochatt

ochatt@dijon.inra.fr

1 Agroécologie, AgroSup Dijon, INRA, Univ. Bourgogne Franche-Comté, 17 rue Sully, 21000 Dijon, France

2 Agritec Plant Research S.R.O., Plant Breeding Section, Zemědělská 2520/16, 78701 Šumperk, Czech Republic

3 Department of Botany, Faculty of Sciences, Palacký University in Olomouc, Slechtitelu 27, 78371 Olomouc, Czech Republic

4 Institute of Field and Vegetable Crops (IFVCNS), Forage Crops Department, Maksima Gorkog 30, 21000 Novi Sad, Serbia 